\title{
Indian social media politics: new era of election war
}

\author{
Keshav Patel $^{1}$, Himani Binjola ${ }^{2}$, Taha Siddiqui ${ }^{2}$ \\ ${ }^{1}$ Mahatma Gandhi Chitrakoot Gramoday University \\ Kamtan, Janki Kund, Chitrakoot, Madhya Pradesh, 485334, Republic of India \\ ${ }^{2}$ Graphic Era Hill University \\ 566/6 Bell Road, Society Area, Clement Town, Dehradun, Uttarakhand, 248002, Republic of India
}

The role of social media during $16^{\text {th }}$ Lok Sabha elections has led to several insights in the manner in which the youth of today is consuming political news. Several social media platforms have played a significant role in voting behaviour. Social media platform acted as a game changer and a catalyst in wooing young voters and influencing their opinion. While Internet users grew 7\% in Urban India reaching 315 million users in 2018, digital adoption is now being propelled by rural India, registering a 35\% growth in Internet users over the past year. Also, there have come a general perception that television will play a lesser role in this upcoming election and digital media will play a never before seen influence on voters. This research examines the behaviour of youth in India and examines the level of influence by social media in casting their vote in Lok Sabha elections. Whether social media can be a game changer or an influencer. These findings will be carried out by this research work.

Keywords: social media, politics, general election

\section{Introduction}

With the advent of Social media definition of expression of thoughts has profoundly changed for the masses and new era of expression is emerging with the dawn of social media. Earlier media usage was restricted to newspapers, magazines, television and radio but with social media definition of media usage has completely changed. Perception of people has eventually transformed for social media earlier social media was only considered as a new technology medium but with changing times social media is not only considered as the medium of information but it is also measured as reliable medium of information [1]. Social media brought change in every domain and astoundingly politics was also not untouched by its magnetism and splendour. $16^{\text {th }}$ Lok Sabha elections witnessed the upsurge of social media and were underway very different from all the previous elections. In Independent India 2014 elections were the elections where social media was used as a weapon to woo 149 billion first time voters and to these first-time voter's

(C) Patel K., Binjola H., Siddiqui T., 2020

(c) (i) This work is licensed under a Creative Commons Attribution 4.0 International License https://creativecommons.org/licenses/by/4.0/ 
social media convention comes easy. This is evidently seen and observed that each and every political party after 2014 elections actually understood that how "NaMo Campaign" of Bharatiya Janata Party (BJP) changed the dynamics of politics and before $16^{\text {th }}$ Lok Sabha elections importance of social media in politics was not that perceptible $[6 ; 2]$.

In earlier times traditional media played a very substantial role in creating awareness among populace but over period of time social media became the primary tool of promotion and publicising because with time social media has proved that it is not only the medium to inform or educate masses but also to fascinate and charm masses. The dearth of social media was not only seen in the $16^{\text {th }}$ Lok Sabha elections but the same was seen in the 2008 US Presidential elections where the value and assistance of social media was proved by Barack Obama's political campaign. In fact every morsel of his political campaign included social media which included its usage in advertising, fund raising, advance work and this was propagated in 50 states. Obama used Twitter, Facebook and YouTube to tell masses how he felt about important issues and his concern for the country. It was evident that US presidential elections changed the dynamics of communication and vitally used the new technology 'social media' for influencing voters and creating impact on voter's behaviour. The same was dispensed in India in 2011 where vigorous usage of social media was seen in movement called "India against Corruption" (IAC). It was clearly seen that primarily social media was used by the organizers and supporters of IAC [3] to earn people support and attract thoughtfulness of people. This movement not only created awareness among masses but it was also seen that social media was a low cost medium of communication for connecting with masses. Power of social media was reflected through IAC and the campaign received massive support by youngsters... [2].

Interestingly the number of Internet users in India has manifolded. According to a report on digital adoption and usage trends in India, by Kantar IMRB's I-CUBE 2018, the number of Internet users in India has exceeded half a billion people in 2018 ! Fixed at a whopping 566 million, the rural Internet usage and growth has also increased man times. The report further says that the number of Internet users in India grew $18 \%$ annually. This figure is estimated at 566 million as of December 2018; a considerable 40\% Internet penetration in India. The report further highlights the probability of double-digit growth for 2019 and estimates that the number of Internet users in India will reach a huge 627 million in 2019 [4]. India has actually seen the revolution of communication with such a fast speediness and has advanced with it. Social media's importance fuelled when India witnessed its influence on US Presidential elections and the way IAC was buoyed by individuals. A speculation about impact of social media is a much-gabbed issue among politicians around elections. Political parties have realized that old fashioned techniques and strategies of campaigning, i.e. posters, cardboard, rallies, house to house canvassing, cut-outs, and promotion vans have to be fuelled with capturing of Internet platforms as well so that each and every individual voter could be tapped and new voters could be influenced. Many politicians have understood that social media is the new need of the hour and will be the new definition of political campaigning. In 2014 there were total of 149 million new voters registered which were 
tech savvy and to them access of social media came easy [1]. In 2019 election 900 million voters registered themselves and in which 15 million new voters aged 18-19 registered themselves.

\section{Literature review}

\section{Classification of social media}

Social media emanates as a network of information and technology which uses communication for user-produced content and interaction and also interpersonal relations are shaped and sustained. Few features that could be identified with social media are collaboration (user groups and user), social networking, use of different sources (blogs, search engines etc.), and participation.

Web 2.0 is also one of the tools of social media. Web 2.0 can also be defined as developments in technology utilized online that allows interactive capabilities in an environment characterised by user control, freedom and dialogue and brings a new degree of interactivity and consumer involvement to advertising applications. It truly enables two way communication between brand and consumer [5].

\section{Social networking influence on Indian youth}

Human beings have perpetually hunted to live in social surroundings. Social networking has emerged as a mass online activity where millions of people are networking through various platforms and are engaged on social media platforms during their ease and work time. If we talk of olden time's man has always been a social animal and through various modes of communication humans have been communicating with each other via various kinesics, insignia language, eruditions, telecommunication and many such modes but times have really altered with institution of social networking sites to hominids. In less than five years these social sites have gained popularity among millions and have made their space in every individual's life whether it is their professional space or personal space. One thing more that is coming in reality is that technological dependence is increasing with each passing day for communication and that is how social networking sites are affecting daily progressions and developments. SNS (social networking sites) have grown from niche online activity into a phenomenon. Parameters of friendship and relations is everyday changing from close to casual acquaintances on various social networking sites, i.e. Friendster, LinkedIn, Facebook where on Facebook it is easy to highlight your relationship status by marking it single, committed or complicated. According to the market research agency Kantar IMRB, India is registering rapid growth in rural areas and India's Internet users are expected to rise in double digits and will grow to 627 million in 2019. Interestingly digital revolution has touched upon small towns and villages and this could only be possible due to increased accessibility and affordable Internet data charges by companies like Jio and Airtel. Rural Indians are now more comfortable in using smartphones and browse Internet to meet their entertainment and information needs.

\section{Social media's influence over Indian politics}

Narratives of politics has eventually changed with social media because election and selection of any candidate is not about getting elected but it has changed 
its meaning from simply elected to getting socially elected. The expression of thought and expressions has gradually changed over with social media, social media is affecting all the senses of individual whether it is writing, thinking, communicating or responding to a situation socially. Degree of expression is also changing with social media where people are freely expressing themselves on various platforms through their writing pieces and blogs. Social media's influence is also over the voting pattern and impacts the manner people vote. Social media is not only the part of new media but is also a democratic tool for the political parties and candidates for persuading voting comportment. With changeable times political parties are not only focused to political rallies, manifesto, political gatherings but digital platforms have become an integral part of political planning. Twitter, YouTube, Google Plus, Facebook, WhatsApp and other media platforms have truly transformed the definition and essence of political promotions. In 2014 Vivekananda Foundation was the think tank of BJP which framed the political draft for making MODI as the hero of nation and made a perception among people that MODI was the political hero and definition of development. They not only used social media platforms but all possible mode of communication i.e. advertisement, interactions for establishing MODI as a brand. In 2014 it was for the very first time on social media where the term "NaMo" was used [6]. Prime Minister Narendra Modi was the one who essentially realized the importance and standing of social media. He was the one who knew that how social media could be used as a boon for connecting with masses and for influencing voters. His team kept no stone unturned for linking with populace and used best possible social media platforms, i.e. Google Hangouts, Facebook, WhatsApp, Twitter and also live webcasts of his speeches.

Change is the definitive desire of the relationship between social media and politics. The civil society is vexing to use social media for revolution. One thing more is to be seen that this online revolution is more about fluctuating human behaviour and less about technology.

Social networking sites can be described as networks of friends for social or professional interactions. Indeed online social networks have absolutely changed the diffusion of information by constructing it easy to share and digest information on the Internet [7].

If we look at the overall perspective of social networking sites it is acting as a prodigious medium for view mobilization. Youth is not only sharing their personal or professional lives on social media platforms but are also outreaching and casting their opinions regarding social issues, i.e. corruption, human rights, gender insensitivity, child trafficking and many more [8] discovered that in German Federal elections relative volume of tweets closely mirrored the results of the German elections. Researchers found that Twitter was used for political deliberation and voters presence was calculated by their tweets. UK Members of Parliament (MPs) have been using Twitter to augment communication with their constituency since 2007. The influence of media on political participation has been studied extensively in the United States [9]. The presidential elections of USA proved the importance of social media in 2008 and Barack Obama made the world realize that social media could be a blessing for politicians. Also, a study by Masahiro Yamamo- 
to and Matthew James Kushin published in Mass Communication and Society, provided acumen into the social media behaviours of young people (adults under the age of 30), a demographic embattled by Barack Obama.

It is established in the study that young minds fetch more of political information from social media platforms than any other age group. It is becoming transparent that social media tools are playing a vital role in setting governmental schemas and shaping public opinion [10]. Journalists, citizens and politicians are adopting various social media platforms for expressing their political ideologies and for engaging various stakeholders for propagating and retrieving information and also contribute to critical-rational deliberation [11]. Therefore, this study is an attempt to understand the impact of social media on Indian politics Understanding perception of youth on social media and its impact on politics The fast changing trends in the media industry has prompted technological shift as well as a drastic change in the consumption of news among the youth. The students of journalism and mass communication have started conceptualizing the profession against the backdrop of rapid changing practices and principles of journalism. There have been several researches done to assess journalism student's perception about the notion of professional media practices in media [12]. Recent developments especially in context of 2014 and 2019 General Elections suggest a strong relationship between social media usage and political engagement in terms of awareness, accountability and participation. The youth of today has become more expressive and responsive to political scenario as compared to previous generation. Keeping the above context in mind, this study seeks to examine the issues with present pedagogic approaches in journalism education in India based on journalism student's perception of social media impact on politics.

\section{Methodology}

A total of five focus group discussions were conducted with students enrolled in Journalism Bachelors program in two different journalism/media department at an Indian University. Each session had 10 participants who were selected based on the submission of a consent form. Discussions were done by a moderator and were also recorded on a digital audio recorder. This was further transcribed and categorised as per the recurring theme and pointers. The responses in regional languages mainly in Hindi were translated into English. The transcripts were then axially coded by the three coders (the first, second and third author of the study) to identify relevant themes and key points. Once the relevant themes were identified and finalized representative quotes were selected after a discussion based on final coding.

\section{Analysis}

Discussions on the following themes were done during the focus group discussions:

1. Choice of social media platform for political news consumption. A discussion revolving around social media platform for news consumption was done in order to assess the choice of journalism students and the reason behind the same. Several participants identified social media platform as their only source of news 
consumption, while others felt that TV news channel and newspapers are better source of political news, for being credible and detailed. However, $83 \%$ of the journalism students believed that social media has changed the public discourse among youth in context of political news and they have become more aware and interested as compared to five years ago.

"Being a journalism student, I have developed interest in political news because everything is easily accessible. All the political news is available on my smart phone. I don't have to go to library to read newspaper or switch on a TV program at a particular time to watch a political discussion".

2. Popular social media platforms among youth. With advent of Internet and consequently social media platforms, there has been an increase in the number of Internet users. As per the Cisco report the number of smartphones users in India is expected to double to 829 million by 2022 from 404.1 million in 2017 [13]. The report further states that by 2022, the smartphone data consumption in India will increase by five times - which proves the dominance of smartphones as the communications hub for social media, news, video consumption, communications, and business purpose. If we look at the social media penetration in India, the most popular social network was YouTube and Facebook having a total penetration narrate of 30 each. On the other hand, WhatsApp was ranked third with $28 \%$ reach. India ranks second among countries having maximum number of $\mathrm{Fa}-$ cebook users, accounting for 11\% of global Facebook audiences in April 2017.

"I feel that since the time I have joined Facebook, I have become more politically aware, especially in context of political news. Although there have been lot of fake news doing the rounds, but amongst all this one is able to sift authentic news. If I was not on social media, I might have not developed interest in general elections 2019. Social media has gained momentum in India with the social movement, 'India against Corruption' and since then there has been no looking back. I am a first-time voter and I regularly use YouTube and news apps for political information and awareness". [6].

3. Social media and credibility factor. There is no doubt that social media has open several platforms for news consumption and with multiple news sources, there is also a rise in fake news and misinformation. In the digital age, where a huge amount of free information is easily accessible in public domain, the problem of misinformation, disinformation and propaganda is quite obvious. While the growing popularity of the use of social media platform, especially Facebook, and its potential to propagate misinformation, the ability to judge credible information is becoming more important. Social media users need to pay attention to information credibility because online rumour may cause serious harm to individuals and society [14]. In the last one month, India has witnessed unprecedented levels of misinformation, lies, and fake statistics being offered to people through their smartphones. Because there is an evident rise in fake news, which is being circulated in a very systematic and organised way, a large chunk of misinformation is being consumed by the public. This in turn leaves the public confused between right and wrong and between fake and real. Although, Facebook has taken several steps to identify fake news articles, false claim as "disputed by $3^{\text {rd }}$ party fact-checkers", show fewer false articles in users' news feeds, and help users avoid accidentally 
sharing false articles by notifying them that a story is "disputed by $3^{\text {rd }}$ parties" before they share it [15].

"Sometimes it becomes very difficult to assess whether a piece of article or a photo is real or fake. I have also felt that there has been more fake news around Lok Sabha elections 2019 and there should be some mechanism to bust this problem" [16].

\section{References}

[1] Patel, K. (2015). Social Media in the Indian Context: New Flavor of the Season. Global Journal of Multidisciplinary Studies, 4(6), 268-270.

[2] Biswas, A., Ingle, N., \& Roy, M. (2014). Influence of Social Media on Voting Behavior. Journal of Power, Politics \& Governance, 2(2), 127-155.

[3] Patel, K. (2018, November). Impact of Advancements in Technological Aids in Communication Media in Bringing About Social Reformation. Global Conference on Journalism and Mass Communication, Colombo, Sri Lanka.

[4] Nayak, D. (2019, 8 March). Internet Users In India Exceeds Half A Billion People In 2018, 97\% Use Mobile To Connect. Dazeinfo. https://dazeinfo.com/2019/03/08/indiaInternet-users-2018-mobile-report/ (accessed: 12.09.2019).

[5] West, A. (2010). Advertising 2.0: social media marketing in a Web 2.0 world. Routledge Journals, Taylor \& Francis Ltd.

[6] Patel, K. (2017). Lok Sabha 2014, Narendra Modi and Social Sites. International Journal of Recent Advances in Psychology \& Psychotherapy, 1(1), 24-28.

[7] Akrimi, Y., \& Khemakhem, R. (2012). What drive consumers to spread the word in social media? Journal of Marketing Research \& Case Studies, (1), 1-14.

[8] Tumasjan, A., Sprenger, T.O., Sandner, P.G., \& Welpe, I.M. (2010). Predicting elections with twitter: What 140 characters reveal about political sentiment (pp. 178-185).

Fourth International AAAI Conference on Weblogs and Social Media.

[9] Chaffee, S.H., \& Kanihan, S.F. (1997). Learning about Politics from the Mass Media. Political Communication, 14(4), 421-430. doi: 10.1080/105846097199218.

[10] Wallsten, K. (2007). Agenda setting and the blogosphere: An analysis of the relationship between mainstream media and political blogs. Review of policy Research, 24(6), 567-587.

[11] Sauter, T., \& Bruns, A. (2013). Social Media in the Media: How Australian Media Perceive Social Media as Political Tools. ARC Centre of Excellence for Creative Industries and Innovation, Brisbane, Queensland, Australia.

[12] Williams, A., Guglietti, M.V., \& Haney, S. (2018). Journalism students' professional identity in the making: Implications for education and practice. Journalism, 19(6), 820-836.

[13] Express Computer. (2018, 5 December). India To Have Over 800 Million Smartphone Users By 2022: Cisco. Retrieved from https://www.expresscomputer.in/Internet/indiato-have-over-800-million-smartphone-users-by-2022-cisco/30512/ (accessed: 20.12.2019).

[14] Li, R., \& Suh, A. (2015). Factors influencing information credibility on social media platforms: Evidence from Facebook pages. Procedia computer science, 72, 314-328.

[15] Allcott, H., \& Gentzkow, M. (2017). Social media and fake news in the 2016 election. Journal of economic perspectives, 31(2), 211-236.

[16] Golan, G., \& Wanta, W. (2001). Second-level agenda setting in the New Hampshire primary: A comparison of coverage in three newspapers and public perceptions of candidates. Journalism \& Mass Communication Quarterly, 78(2), 247-259.

\section{Article history:}

Received: 22 September 2019

Revised: 30 October 2019

Accepted: 28 November 2019 


\title{
For citation:
}

Patel, K., Binjola, H., \& Siddiqui, T. (2020). Indian social media politics: New era of election war. RUDN Journal of Studies in Literature and Journalism, 25(1), 184-192. http:// dx.doi.org/10.22363/2312-9220-2020-25-1-184-192

\section{Bio notes:}

Keshav Patel, researcher (academic), Department of Communication, Mahatma Gandhi Chitrakoot Gramodaya University. E-mail:mgcgv@rediffmail.com

Himani Binjola, Assistant Professor, Department of Media \& Mass Communication, Graphic Era Hill University (GEHU). E-mail: enquiry@gehu.ac.in

Taha Siddiqui, Assistant Professor, Department of Media \& Mass Communication, Graphic Era Hill University (GEHU). E-mail: enquiry@gehu.ac.in

Научная статья

\section{Индийская политика социальных медиа: новая эра избирательных процессов}

\author{
К. Патель ${ }^{1}$ Х. Бинжола ${ }^{2}$, Т. Сиддики ${ }^{2}$ \\ ${ }^{1}$ Университет Махатмы Ганди Читракут Грамодайа \\ Республика Индия, 485334, Мадхья-Прадеш, Читракут, Джсанки Кунд, Камтан \\ ${ }^{2}$ Университет График Эра Хилл \\ Республика Индия, 248002, Уттаракханд, Дехрадун, Клемент Таун, \\ Общественная зона, Белл-роуд, 566/6
}

Социальные сети сыграли важную роль в период 16-х выборов в нижнюю палату парламента Индии, что стало поводом для анализа поведения современной молодежи при получении политических новостей. Сегодня соцсети вовлекают молодых избирателей в коммуникацию и формируют их мнение. Число пользователей Интернета в городах Индии выросло на 7 \% и достигло 315 миллионов пользователей. В настоящее время в сельских районах Индии активно внедряется цифровое вещание, за последний год число пользователей Интернета увеличилось на $35 \%$. Прогнозируется, что роль телевидения уменьшится в период предстоящих выборов, на избирателей будут оказывать огромное влияние цифровые СМИ. В статье представлены результаты исследования поведения молодежи, изучено влияния соцсетей на голосование. Ставится вопрос - можно ли признать социальные сети фактором, существенно влияющим на молодежь в период выборов.

Ключевые слова: социальные медиа, политика, всеобщие выборы

\section{История статьи:}

Дата поступления в редакцию: 22 сентября 2019

Дата принятия к печати: 28 ноября 2019

\section{Для цитирования:}

Patel K., Binjola H., Siddiqui T. Indian social media politics: new era of election war (Индийская политика социальных медиа: новая эра избирательных процессов) // 
Вестник Российского университета дружбы народов. Серия: Литературоведение. Журналистика. 2020. Т. 25. № 1. С. 184-192. http://dx.doi.org/10.22363/2312-92202020-25-1-184-192

\section{Сведения об авторах:}

Патель Кешав, исследователь (академик), департамент коммуникаций, Университет Махатмы Ганди Читракут Грамодайа. E-mail: mgcgv@rediffmail.com

Бинжола Химани, доцент кафедры средств массовой информации и массовых коммуникаций, Университет График Эра Хилл. E-mail: enquiry@gehu.ac.in

Сиддики Taxa, доцент кафедры средств массовой информации и массовых коммуникаций, Университет График Эра Хилл. E-mail: enquiry@gehu.ac.in 